\title{
Influence of Education, Experience, and Location on Work Satisfaction in Micro, Small and Medium Enterprises in Nigeria
}

\author{
Adeleke Oladapo Banwo ${ }^{1}$, Jianguo $\mathrm{Du}^{1} \&$ Uchechi Onokala ${ }^{2}$ \\ ${ }^{1}$ School of Management, Jiangsu University, Zhenjiang, Jiangsu Province, China \\ ${ }^{2}$ University of Lagos, Nigeria \\ Correspondence: Adeleke Oladapo Banwo, School of Management, Jiangsu University, Zhenjiang, Jiangsu \\ Province, China. E-mail: lekebanwo@gmail.com
}

Received: March 14, $2015 \quad$ Accepted: April 11, $2015 \quad$ Online Published: May 31, 2015
doi:10.5539/jms.v5n2p119
URL: http://dx.doi.org/10.5539/jms.v5n2p119

\begin{abstract}
The purpose of this study was to examine the influence of work experience, education and location on work satisfaction in Micro, Small and Medium Enterprises (MSMEs) in Nigeria. A survey design of employees in 450 MSMEs across four states and business segments were used; 375 employees (83\%) respondents were suitable for analysis. The Questionnaire measured demographics, location, education and experience as variables and data was analyzed using regression and correlation. The results suggest a significant positive relationship between educational qualifications, location and work satisfaction and negative correlation of previous experience and work satisfaction.
\end{abstract}

Keywords: education, location, micro, small and medium Enterprises (MSMEs), Nigeria, work experience, work satisfaction

\section{Introduction}

Micro, small and medium enterprises (MSMEs) exist and evolve in economic systems performing active roles in reducing poverty, economic empowerment and growth (Beck, Demirguc-Kunt, \& Levine, 2005; Okpara, 2011). The abundance of research and scholarly works on MSMEs is a pointer to their relevance and complex social networks in which they are entangled in economies. They exist within frameworks of a geographical space and national boundaries with diverse human and organizational behavior prevalent in their economic domains.

The importance of these entities is buttressed by Cyert and March (1992) view of 'organizations as coalition of diverse subgroup and complex system in which decisions are made at different levels' stressing the dynamics , interplay of endogenous and exogenous elements moulding them in their respective economies (George, Owoyemi, \& Kuye, 2012). Employees and owners of these enterprises operate in environments classified as stable, uncertain (Lawrence \& Lorsch, 1967), with those in developing economies operating in placid, disturbed, turbulent environment (Emery \& Trist, 1965) also the organization-environment relationship includes industry structure, technology, government regulations, and culture (Abe \& Dutta, 2014; Aldrich, 2007; Daft, 2010; Pfeffer \& Salancik, 2003). These environmental elements dictate and influence their level of contribution to economy growth and type of employees hired.

MSMEs are active stakeholders and key actors in economic growth and development of their countries and like human cells possess DNAs which has sustained their survival and evolution in line with environmental dictates. However, despite the volume of research and institutional support given to them, there remains a gap in comprehending factors influencing work satisfaction in Nigerian SMEs. Scholarly literature reiterate the critical role they play as fulcrum, engine of growth, major contributors to gross domestic performance (GDP) and job creation (Ayyagari, Demirgüç-Kunt, \& Maksimovic, 2011; Beck \& Demirgüç-Kunt, 2005; Ruzzier, Ruzzier, \& Hisrich, 2013).

Majority of research on MSMEs in Nigeria have focused on constraints such as lack of access to finance, multiple taxation, dimensions of environment with resultant blame on conventional financial institutions and government for their plight and state (Ayyagari, Beck, \& Demirguc-Kunt, 2007; Johnson, George, Owoyemi,\& Adegboye, 2013; Osotimehin, Jegede, Akinlabi, \& Olajide, 2012; Oyelaran-Oyeyinka, 2008).

This paper aims to contribute to the body of literature on understanding MSMEs in developing economies which 
has often been neglected and is structured in two segments; the first provides insight on key actors within the MSME framework. The second discusses the conceptual framework, relevant theories and tests the following Hypotheses:

Hypothesis 1: Is there significant relationship between educational qualification and work satisfaction of employees in MSMEs?

Hypothesis 2: Is there significant relationship between experience and work satisfaction of employees in MSMEs?

Hypothesis 3: Is there significant relationship between location and work satisfaction of employees in MSMEs?

\subsection{The Nigerian Influence}

Nigeria provides an interesting economic context to examine MSMEs because of her strategic position in the African continent in terms of size and uneven distribution of economic resources in the different states. In studying MSMEs, critical efforts should be made to study their internal composition, group dynamics and context in terms of locations (Bennett, Robson, \& Bratton, 2001; Porter, 1994), educational qualification (Hussain, Millman, \& Matlay, 2006) and objectives of its stakeholders as critical for designing policy, tailoring home-grown support in their locations and capacity building.

'In other to understand contemporary economic decision making within business organizations, the study of market factors needs to be supplemented with an examination of the internal operations of firms to understand the effects of organizational structure and conventional practice on the development of goals, the formation of expectations and execution of choices' (Cyert \& March, 1992, p. 1).

\subsection{Nigerian MSMEs Development Framework}

According to Nigeria's 2010 National MSME Collaborative survey, MSMEs contributed $46.54 \%$ to Nigeria's GDP in nominal terms and a major employer of labor; with 17,284,671 MSMEs employing 32,414,884 persons'. This depicts their crucial role in alleviating poverty and though they are found in clusters; their task environments is subject to the interplay of location, relevant experience and education (Ropega, 2011).

MSMEs in major locations (see Table 3) have distinct features, classification, and (see Table 1) influenced by soft factors, nature of business, formal and informal education, relevant work experience and life cycles. These enterprises leverage on opportunities and innovation capabilities borne out of desire to evade poverty at the bottom of pyramid to sustain their presence. Inferences from the National Technical Working Group on Small and Medium Enterprises report (2009) affirms that majority of MSMEs are family-owned, with low capital base and mostly in urban and semi-urban areas ,possessing latent innovative tendencies, with access to multiple social networks and several shades of behavioural styles and employees (Moreno,1934).

\subsection{Micro, Small and Medium Enterprises}

In all facet of developing economies, micro and informal businesses are predominant with low skills, minimal entry requirements and confronted with poor transition to small and medium enterprises due to lack of capacity, and literacy levels. At this level, survival need is a major driving force rather than work satisfaction to meet the basic needs of food, clothing and shelter and desire to be engaged in some sort of activity to escape unemployment (Binder \& Coad, 2013). The informal nature enables them to exist in locations where they find space, though they possess low formal education, they understand the dynamics of their terrain and easily source funds from traditional "Ajo" (thrift savings) collector. Participation in group savings helps them in meeting target expenses and building up financial discipline.

The informal and micro enterprises terrain in sub-Saharan Africa remains a focus of attention for researchers and scholars despite the dearth of data (Porta \& Shleifer, 2014). Their transient nature makes it difficult for agencies and researchers to accurately determine their numbers, though they are the most business setups in Africa. The existence of a virile informal financial mechanism continues to thrive mainly ,due to imbalances in the system, distress syndrome of traditional banks, fraud and a plethora of regulator-operator induced problems making the un-banked (informal sector) in developing economies to develop apathy, preferring to patronize their traditional thrift savings systems which are concealed in their norms and cultural values.

In addition, small enterprises have simplified business approach and depending on the quality of human capital, they exhibit process innovation in sustaining competitive advantage in their clusters. Unlike micro enterprises they usually have large number of educated, technically skilled proprietors and employees thereby having easier access to bank credit. Though small enterprises are perceived to have a higher level of education and formal structures, their linkage with micro enterprises are intertwined in most business. Thirdly, majority of medium 
enterprises are in manufacturing, construction, haulage, cottage and ICT sectors and enjoy easier access to credit provided they are not start-ups; from financial institutions and government initiatives unlike small enterprises; that see these initiatives as skewed to favor certain sectors like agriculture and manufacturing .They experience bottlenecks and engage in exchanges with their task environment and domains (Thompson, 2011) by embracing strategic relationships as suppliers, contractors, vendors to multinationals and blue chip organizations to gain competitive edge. This adaptive nature fosters symbiotic relationship and they tend to operate open systems with high level of flexibility and innovation (Banwo, Jianguo, \& Onokala, 2015).

Table 1. Classification of micro, small and medium enterprises

\begin{tabular}{llll}
\hline Size/Category & Employment & $\begin{array}{l}\text { Assets } \\
\text { (Excluding land and building) }\end{array}$ & $\begin{array}{l}\text { Assets (USD*, Thousands) } \\
\text { (Excluding land and building) }\end{array}$ \\
\hline Micro Enterprises & $0 \geq 10$ & $\geq \$ 5$ & $\geq \$ 30$ \\
Small Enterprises & $10 \geq 49$ & $\$ 5 \geq \$ 50$ & $\$ 30 \geq \$ 302$ \\
Medium Enterprises & $50 \geq 199$ & $\$ 50 \geq \$ 500$ & $\$ 302 \geq \$ 3,025$ \\
\hline
\end{tabular}

* Equivalent N165:\$1

Source: Adapted from the Nigeria's National Policy Report, 2009.

\subsection{Employees}

The classification of MSMEs using class band does not take cognizance of underlying issues characterizing the nature of these employees contextually (Edwards, Sengupta, \& Tsai, 2010; Okpara \& Kabongo, 2011). For example an MSME in Nigeria and China with same number of employees and owners who have equal educational qualifications, resources would perform differently due to their internal composition, group dynamics, motivational drive, economic climate and framework.

March and Simon (1958) affirms 'employees exist in organizations or groups which are assemblages of interacting human beings and are the largest assemblages that have semblance to a central coordinate system, the high specificity of invisible structure and coordination within organization, as contrasted with the diffuse and variable relations among organizations and among unorganized individuals marks off the individual organizations as a sociological unit comparable in significance to the individual organism in biology'.

The skill of employees varies across industries in different locations, these skill sets are acquired by formal and informal education commonly referred to as apprenticeship. Institutional and cultural dimensions of work experience, education and location provide bases to examine their work satisfaction.

\subsection{Key Actors}

The Central Bank Of Nigeria, International Finance Corporation, Small and Medium Enterprises Agency Development Of Nigeria (SMEDAN), Nigerian Association of Small Scale Industrialists (NASSI), Nigerian Association of Small and Medium Enterprises (NASME) and Commercial Banks are major stakeholders and custodians of colossal funds aimed at revitalizing these enterprises. The failure of small businesses in developed and developing countries is closely related to their life-cycle stage, endogenous and exogenous elements in their environment and interplay of location, relevant experience, formal and informal education (Ropega, 2011).

Small businesses in Nigeria confront peculiar myriad of problems (Ekpenyong \& Nyong, 1992) and have grown since the advent of the adoption of the Structural Adjustment Programme (SAP) to fill the supply gap in industrial consumer goods created by the difficulties faced by large scale firms which had not easily adapted to the policy changes of SAP (Olorunshola, 2003, p. 34).

\section{Conceptual and Theoretical Frameworks}

Our knowledge of MSMEs is enhanced by applying a mix of theoretical perspectives, research designs and context in relation to their soft and hard environment, hence shedding light on the relationship and effect of dependent variables (location, relevant experience, formal and informal education) and independent variable (work satisfaction).The context of the study necessitated the mix of Penrose Resource based theory and Garbage theory.

First Penrose resource based view has continued to attract attentions of scholars and undergone several modifications (Anderson \& Eshima, 2013; Wernerfelt, 1995), these perspectives stress the existence of market imperfections, heterogeneity of firms, degrees of specialization, corporate resources and usage in the analysis of 


\section{SME innovations.}

The ability of enterprises to leverage on its internal resources provides a buffer in its boundary spanning roles and makes work satisfaction a function of location, relevant experience, informal and formal education (Millán, Hessels, Thurik, \& Aguado, 2013). The uneven economic potential and absorptive capacity in most states is a major driving force for the rate at which MSMEs co-exist in urban and semi-urban areas. States with significant government presence in terms of establishments, agencies, institutions such as schools, universities, business incubation centers, ministries and ports enjoy a spill-over effect of activities and services which are a major contributing factor to the prevalence of these enterprises in Lagos State. It is pertinent to note that urban areas offer proximity, improved infrastructure but those in the semi-urban areas like Ogun, Kano and Abia State benefit from proximity to raw-materials and resources in their location. These locations provide unique resource advantages that are missing in urban areas, such as lower cost of living and doing business and strong cultural institutional frameworks. The resource advantage enables these states to serve as conduits in the supply chain for the exports.

However the absence of clear cut formal strategies by these enterprises stifles their growth and the assumption that failure rates are higher in urban areas among employees and owners that have a higher education level than in the rural areas where owners and employees have little or no formal education but rather provides a basis for inquiry on why failure rate is higher in the urban areas despite the perceived location benefits. This is in sharp contrast to (Ekpenyong \& Nyong, 1992) findings that most of the failure of MSMEs is due to their low level of education and lack of prior business experience.

However, resource dependence theorists view organizations as engaged in exchanges with the environment to improve performance and increase their chances (Pfeffer \& Salancik, 2003)therefore focusing on the external environment in isolation without examining the internal dynamics is narrow and reinforces the impact and role of culture, spatial relationships, geographical boundaries, employee and organizational characteristics, as resource determinants.

Cohen, March, and Olsen (1972) Garbage can model also has been subjected to several revisions, (Olsen, 2001) but still reinforces existence of uncertainty, unstructured spatial relationships in every organization. Enterprises in sub Saharan Africa operate in volatile economies adopting short term reactive strategies to combat environmental influences (Child \& Hsieh, 2014). Their unstable business environment makes 'garbage can model' relevant to MSMEs in Nigeria (Brooks, 2008) combined with soft factors like culture, technology, electricity, ethics and values. These cultural dimensions, differences in mental programming becomes evident in their disposition (George et al, 2012) and serves as a pointer to some of the underlying reasons for their nature. Likewise, Cohen et al. (1972) assertion that these organizations are characterized by three independent streams (problematic problems, unclear technology, and fluid participants) suggests a thought process that conceives the importance of understanding their heterogeneous relationship.

In celebrating GCM's $40^{\text {th }}$ Anniversary, scholars share divergent opinions on the elements and scope of this tested paradigm and advocate for a hybrid model (Lomi \& Harrison, 2012) to introduce behavioral rules (Fioretti, 2012) without undermining the importance and relevance of the theory. Its main proponent predicts a convolution of its loose couplings in the future (Cohen, March, \& Olsen, 2012) and reiterates three key issues relevant to this research.

\subsection{Problematic Preferences}

The pursuit of multiple objectives by employees and stakeholders remains a major hindrance, interviews with some respondents and owners reveal conflicting interest and preferences among internal participants of these enterprises. Employees pursue personal interest to meet their basic economic needs and owners adopt reactive strategies to prioritize their preferences. These conflicting preferences serve as a haven for other problems which prevent them from flourishing and stunting their growth. The inability to have a definite action plan hinders their growth rate and life cycle due to the intertwined nature of elements in their environment.

\subsection{Unclear Technologies}

Most enterprises in developing economies in Africa are disadvantaged with regards to technology when compared with their counterparts in western nations; however they exhibit inclinations for technology acquisition through imitations and process innovations in a bid to remain competitive even in the midst of electricity shortage. World Bank and MSME data-sets indicate that over $75 \%$ of enterprises identified lack of access to electricity as a major problem hindering their business, with resultant negative effect on technological usage tending towards imitations based on trial \& error. The development of e-commerce platforms is more 
common in urban areas and dependent on third party vendors, while some of the enterprises engage in local fabrication, they often lack the capacity to develop it for commercial purposes in a large scale.

\subsection{Fluid Participation}

MSMEs are often confronted with job insecurity, high turnover and constant exchanges with their environment. Their organizational boundaries are fragile, uncertain and poor objective decision making process. Interviews with some respondents reveal that most employees take up jobs primarily to meet their basic necessities regardless of the job requirements, approximately $28 \%$ of employees in the sample indicated their interest and willingness to remain in their jobs for upwards of 1 year and over $62 \%$ are ready to change jobs in less than a year. The nature of SMEs and their structures determines the tenure of employee participation; SMEs that have formalized structures and good reward systems are able to retain their employees when compared to SMEs with no structures and poor reward systems. Attracting the right employees with relevant skill sets is a major problem confronting SMEs coupled with the high level of unemployment in most urban locations.

\section{Method and Results}

Primary data was obtained using interviews, National MSME collaborative survey datasets, questionnaires administered to employees in 450 SMEs in four states spread across the North (Kano State), East (Abia State) and Western States (Lagos and Ogun States) with verbal translations in Ibo, Yoruba, Hausa languages to mitigate barriers arising from uneven literacy levels. Purposive sampling was used to derive the ideal population sample in the three geographical zones; this non-probability method offers the benefit of using a target sample that fits our research inquiry (Rowley, 2014; Teddlie \& Yu, 2007). The interviews and discussions provided practical experience and realities of MSMEs in their daily activities.

The questionnaire design focused on the following four variables: education level, work satisfaction, location and experience. The educational qualification distribution reveals that majority of respondents are bachelors degree holders $(53 \%)$, primary school certificate holders (35\%), and postgraduate holders $(12 \%) .53 \%$ of the respondents were from Lagos state, 25\% (Ogun State), 9\% (Kano State) and 13\% (Abia State).The demographic profile range and percentages are as follows: $21-30$ years $(9.6 \%), 31-40(63.5 \%), 41-50(20 \%)$ and 51 and above $(6.9 \%)$. The differences in the structure of respondents present a multi-cultural dimension and robustness to our research.

Table 2. Education and years of experience of respondents

\begin{tabular}{|c|c|c|c|c|c|c|}
\hline & \multicolumn{6}{|c|}{ Educational } \\
\hline & & & Post & & & \\
\hline & Primary & Bachelors & Graduate & & & \\
\hline & School & Degree & Degree & $0-1$ & $1-3$ & $3-5$ \\
\hline Micro & 83 & 25 & 2 & 65 & 22 & 23 \\
\hline Small & 17 & 96 & 18 & 13 & 88 & 29 \\
\hline Medium & 31 & 78 & 25 & 15 & 29 & 77 \\
\hline Total & 131 & 199 & 45 & 93 & 139 & 129 \\
\hline
\end{tabular}

Source: Field Survey questionnaires.

Table 3. Sectoral classification of respondents

\begin{tabular}{lllll}
\hline Sectors & Lagos & Ogun & Kano & Abia \\
\hline Agriculture,Forestry,Livestock & 23 & 42 & 16 & 30 \\
Retail & 98 & 27 & 8 & 14 \\
Haulage & 30 & 11 & 7 & 3 \\
Manufacturing, Cottage & 49 & 12 & 2 & 3 \\
& 200 & 92 & 33 & 50 \\
\hline
\end{tabular}

Source: Field Survey questionnaires. 
Table 4. Correlation between educational qualification, experience of respondents, location of respondents and work satisfaction

\begin{tabular}{|c|c|c|c|c|}
\hline & 1 & 2 & 3 & 4 \\
\hline Educational Qualification & 1 & & & \\
\hline \multicolumn{5}{|l|}{1 Sig.(2-tailed) } \\
\hline $\mathrm{N}$ & 375 & & & \\
\hline Experience of Respondents & -0.077 & 1 & & \\
\hline 2 Sig. (2-tailed) & 0.137 & & & \\
\hline $\mathrm{N}$ & 375 & 375 & & \\
\hline Locations of Respondents & -0.076 & -0.098 & 1 & \\
\hline 3 Sig. (2-tailed) & 0.144 & 0.058 & & \\
\hline $\mathrm{N}$ & 375 & 375 & 375 & \\
\hline Work satisfaction & $0.242 * *$ & $-0.194 * *$ & $0.186 * *$ & 1 \\
\hline 4 Sig. (2-tailed) & 0.000 & 0.000 & 0.000 & \\
\hline $\mathrm{N}$ & 375 & 375 & 375 & 375 \\
\hline
\end{tabular}

Hypothesis 1: Is there significant relationship between educational qualification and work satisfaction of employees of MSMEs?

This relationship was tested using Pearson moment correlation statistical analysis as presented in Table 4. The result showed significant positive correlation between educational qualification and work satisfaction $(r=0.242$; $\mathrm{P}<0.01$ ), implying a positive relationship between educational qualification and work satisfaction. The positive relationship means that the higher the educational qualification of the employee, the higher the amount of work satisfaction from their work.

The positive relationship between work satisfaction as a dependent variable, educational qualification and location as independent variables represents the first key findings of this study. It is instructive to state that qualifications are not tied to any segments of MSMEs, interviews reveal the following as key factors that influence people to work in MSMEs: work schedule flexibility, poverty level and loss of previous corporate employment. The effect of formal and informal education on MSMEs in the urban, rural and semi-urban areas was not tested. Interviews with a cross-section of respondents shows that MSMEs in rural and semi-urban locations have more committed employees, longer business life span, and lower failure rate when compared to their counterparts in urban locations due to the prevalence and effectiveness of "apprenticeship" style of informal education, influence of soft cultural structures in their environment(Aggarwal,2013;Meagher,1995). The effectiveness of the apprenticeship model is seen mostly in informal markets and enterprises whose owners had little formal education.

Hypothesis 2: Is there significant relationship between experience and work satisfaction of employees of MSMEs?

Based on the Pearson moment correlation results shown in Table 4, a negative correlation exists between years of experience and work satisfaction $(\mathrm{r}=-0.194 ; \mathrm{P}<0.01)$ and suggests that as an employee spends more years working in MSME, the level of their work satisfaction decreases.

The negative relationship between work satisfaction and the years of experience of respondents is rather disturbing. Drawing from the industry demographics of respondents in each location, retail businesses accounted for $40 \%$ while agriculture, haulage and manufacturing accounted for 30\%, 14\% and 18\% respectively. The skill sets in most retail and agricultural businesses in most locations of Nigeria requires minimal experience for young entrants into the apprenticeship informal training sphere, thus indicating that most MSMEs in these industries rely on a large pool of unskilled labour. The low level of educational qualification of unskilled workers limits their ability to secure better employment opportunities. Evidence from our study suggests that the negative relationship between work experience and work satisfaction is closely related to the type of skill level, nature of business and point of entry of participants in the business life cycle. Policy makers and institutional agencies interested in the growth of this virile industry have identified the absence of relevant experience as one of the major causes of MSMEs failures (Olawale, \& Garwe, 2010; Franco \& Haase, 2010).

Hypothesis 3: Is there significant relationship between location and work satisfaction of employees of MSMEs? 
The Pearson moment correlation analysis shows a significant positive correlation between respondents' location and work satisfaction $(\mathrm{r}=0.186 ; \mathrm{P}<0.01)$, implying that there is a positive relationship between respondents' location and work satisfaction

Location of MSMEs plays a major role in determining their success because it determines the type of employee skill set that they have access to, business nature and amount of opportunities they can access. Majority of agricultural based MSMEs are in rural and semi-urban locations with strong cultural norms. The geographical distribution of MSMEs based on National MSME collaborative survey report (2010) is tied to the benefits, opportunities and economic activities in each locations. Previous studies by Porter (2000) assert that location itself does not offer much benefits but rather the nature of competition and economic activity. The nature of economic activities in Lagos, Ogun, Abia and Kano differ sharply and this has had immense influence on the volume of business and wealth created. For instance, cost of living is lower in Ogun State compared to Lagos State and a larger pool of unskilled labour is available in Abia and Kano state. Understanding the economic motivations of these employees would enhance their productivity and result in higher levels of work satisfaction. This is reflected in the constant movement and exchanges to meet demands and maximize opportunities in other locations.

\section{Conclusion and Recommendation}

The study complements MSMEs research on work satisfaction in a developing country and provides empirical evidence on the dimension of relationship between work satisfaction as a dependent variable and work experience, educational qualification and location as independent variables (Mulinge \& Mueller, 1998). A major finding of this study is the negative relationship that exists between work satisfaction and number of years of experience that an employee possesses.

The study has tremendous implications for a broad set of stake holders, multinational corporations and government agencies. Stakeholders are able to understand how soft and hard factors influence and shape employee behavior. This enables them to design home-grown strategies that are relevant to the contextual economies of their home country. While multinational corporations continue their search for cheap labour and raw materials in developing countries, there is a strong need for them to develop a local knowledge of the socio-cultural factors that impact work satisfaction among employees in developing countries (Thornton, Ribeiro-Soriano \& Urbano, 2011).

Although there is a positive relationship between educational qualification and work satisfaction; policy makers and financial institutions' attention should not wrongly conclude that the educational qualification of the business can be linked to the success of their business enterprise.

The intertwined effects of experience, education and location present a mirror to understand the internal configurations of these enterprises, their group dynamics and management. The economic benefits of managing the interplay of these variables and other contextual elements present an opportunity to address some issues plaguing the growth of MSMEs in developing countries.

This study was limited to a developing nation and not generalizable and did not examine the role culture plays in influencing values in the Nigerian context; future studies should incorporate culture and investigate demographic influences. Also cross-country studies of two or more countries within the same region are advocated to make the findings robust.

\section{Acknowledgments}

The authors are indebted to anonymous reviewers for their insightful comments, constructive suggestions, which helped improve the quality of this paper.

This work was supported in part by the National Natural Science Foundation of China under grants 71471076, 71171099, 71373818 and 71201071 and by the Joint Research of The NSFC-NRF Scientific Cooperation Program under grant 713111111, and by the Research Fund for the Doctoral Program of Higher Education under grant 20123227110011. This work was also sponsored by Qing Lan Project and 333 Project of Jiangsu Province, and Jiangsu University Top Talents Training Project.

\section{References}

Abe, M., \& Dutta, M. K. (2014). A new policy framework for Myanmar's SME development (No. 142). ARTNeT Working Paper Series.

Aggarwal, A. (2013). Lessons learnt from informal apprenticeship initiatives in Southern and Eastern Africa. Minister of Higher Education and Training Declaration of: The year of the Artisan, 4 Feb 2013 "It's cool to 
be an Artisan" We are here today with the Deputy Minister of Higher Education, 113.

Aldrich, H. (2007). Organizations and environments. Stanford University Press.

Anderson, B. S., \& Eshima, Y. (2013). The influence of firm age and intangible resources on the relationship between entrepreneurial orientation and firm growth among Japanese SMEs. Journal of Business Venturing, 28(3), 413-429.

Ayyagari, M., Beck, T., \& Demirguc-Kunt, A. (2007). Small and medium enterprises across the globe. Small Business Economics, 29(4), 415-434. http://dx.doi.org/10.1007/s11187-006-9002-5

Ayyagari, M., Demirgüç-Kunt, A., \& Maksimovic, V. (2011). Small vs. young firms across the world: contribution to employment, job creation, and growth. World Bank Policy Research Working Paper, (5631). http://dx.doi.org/10.1596/1813-9450-5631

Banwo, A. O., Jianguo, D., \& Onokala, U. (2015). Symbiotic Innovative Relationships of Small and Medium Enterprises. Journal of Advanced Management Science, 3(2).

Beck, T., Demirguc-Kunt, A., \& Levine, R. (2005). SMEs, growth, and poverty: cross-country evidence. Journal of economic growth, 10(3), 199-229. http://dx.doi.org/10.1007/s10887-005-3533-5

Bennett, R. J., Robson, P. J., \& Bratton, W. J. (2001). The influence of location on the use by SMEs of external advice and collaboration. Urban Studies, 38(9), 1531-1557. http://dx.doi.org/10.1080/00420980120076795

Binder, M., \& Coad, A. (2013). Life satisfaction and self-employment: a matching approach. Small Business Economics, 40(4), 1009-1033. http://dx.doi.org/10.1007/s11187-011-9413-9

Brooks, I. (2008). Organisational behaviour: individuals, groups and organization. Pearson Education.

Child, J., \& Hsieh, L. H. (2014). Decision mode, information and network attachment in the internationalization of SMEs: A configurational and contingency analysis. Journal of world Business, 49(4), 598-610. http://dx.doi.org/10.1016/j.jwb.2013.12.012

Cohen, M. D., March, J. G., \& Olsen, J. P. (1972). A garbage can model of organizational choice. Administrative science quarterly, 1-25. http://dx.doi.org/10.2307/2392088

Cohen, M. D., March, J. G., \& Olsen, J. P. (2012). A garbage can model at forty: A solution that still attracts problems. The garbage can model of organizational choice: Looking forward at forty, 36, 19-30. http://dx.doi.org/10.1108/S0733-558X(2012)0000036005

Cyert, R. M., \& March, J. G. (1992). A behavioural theory of the firm.

Daft, R. (2010). Organization theory and design. Cengage Learning.

Edwards, P., Sengupta, S., \& Tsai, C. J. (2010). The context-dependent nature of small firms' relations with support agencies: A three-sector study in the UK. International Small Business Journal. http://dx.doi.org/10.1177/0266242610375769

Ekpenyong, D. B., \& Nyong, M. O. (1992). Small and medium-scale enterprises in Nigeria: their characteristics, problems and sources of finance.

Emery, F., \& Trist, E. (1965). The causal texture of organizational environments. Human relations, 18, 12-32. http://dx.doi.org/10.1177/001872676501800103

Fioretti, G. (2012). Garbage Can Ecologies: An Agent-Based Exploration. The Garbage Can Model of Organizational Choice: Looking Forward at Forty, 36, 141-164. http://dx.doi.org/10.1108/S0733-558X(2012)0000036009

Franco, M., \& Haase, H. (2010). Failure factors in small and medium-sized enterprises: qualitative study from an attributional perspective. International Entrepreneurship and Management Journal, 6(4), 503-521. http://dx.doi.org/10.1007/s11365-009-0124-5

George, O. J., Owoyemi, O., \& Kuye, O. (2012). Impact of Hofstede's (1980, 2001)'Software of the Mind'on the Transfer of Management Practices: The Case of the Transfer of the British Voluntarist Employment Relations Practice to Nigeria'. Journal of Management and Strategy, 3(4), 55.

Hussain, J., Millman, C., \& Matlay, H. (2006). SME financing in the UK and in China: a comparative perspective. Journal of Small Business and Enterprise Development, 13(4), 584-599. http://dx.doi.org/10.1108/14626000610705769

Johnson, F. O., George, O., Owoyemi, O., \& Adegboye, M. (2013). Effects of Socio-Cultural Realities on the 
Nigerian Small and Medium Sized Enterprises (SMEs): Case of Small and Medium Sized Enterprises in Lagos State. International Journal of Business and Management, 9(1), 90.

Lawrence, P. R., \& Lorsch, J. W. (1967). Differentiation and integration in complex organizations. Administrative science quarterly, 1-47. http://dx.doi.org/10.2307/2391211

Lomi, A., \& Harrison, J. R. (2012). The garbage can model of organizational choice: looking forward at forty. $\begin{array}{llllll}\text { Research in the Sociology of } & \text { Organizations, } & 36, & 3-17 .\end{array}$ http://dx.doi.org/10.1108/S0733-558X(2012)0000036004

March, J. G., \& Simon, H. A. (1958). Organizations Wiley. New York, 262.

Meagher, K. (1995). Crisis, Informalization and the Urban Informal Sector in Sub-Saharan Africa. Development and Change, 26(2), 259-284.

Millán, J. M., Hessels, J., Thurik, R., \& Aguado, R. (2013). Determinants of job satisfaction: a European comparison of self-employed and paid employees. Small Business Economics, 40(3). 651-670.http://dx.doi.org/10.1007/s11187-011-9380-1

Moreno, J. L. (1934). Who shall survive? A new approach to the problem of human interrelations. http://dx.doi.org/10.1037/10648-000

Mulinge, M., \& Mueller, C. W. (1998). Employee job satisfaction in developing countries: the case of Kenya. World Development, 26(12), 2181-2199.

National MSME Collaborative Survey Report. (2010). Retrieved from http://www.nigerianstat.gov.ng/pages/download/67

Okpara, J. O. (2011). Factors constraining the growth and survival of SMEs in Nigeria: Implications for poverty alleviation. Management Research Review, 34(2), 156-171. http://dx.doi.org/10.1108/01409171111102786

Okpara, J. O., \& Kabongo, J. D. (2011). Cross-cultural training and expatriate adjustment: A study of western expatriates in Nigeria. Journal of World Business, 46(1), 22-30. http://dx.doi.org/10.1016/j.jwb.2010.05.014

Olawale, F., \& Garwe, D. (2010). Obstacles to the growth of new SMEs in South Africa: A principal component analysis approach. African Journal of Business Management, 4(5), 729-738.

Olorunshola, J. A. (2003). Problems and prospects of small and medium scale industries in Nigeria. In Central Bank of Nigeria Seminar on Small and Medium Industries Equity Investment Scheme (SMIEIS) CBN training Centre, Lagos, pp. 34-49.

Olsen, J. P. (2001). Garbage cans, new institutionalism, and the study of politics. In American Political Science Association, 95(1), 191-198. Cambridge University Press.

Osotimehin, K. O., Jegede, C. A., Akinlabi, B. H., \& Olajide, O. T. (2012). An evaluation of the challenges and prospects of micro and small scale enterprises development in Nigeria. American International Journal of Contemporary Research, 2(4), 174-185.

Oyelaran-Oyeyinka, B. (2008). SME: Issues, Challenges and Prospects. In Invited presentation at the CBN Financial Sector Strategies (FSS) International Conference, Abuja.

Pfeffer, J., \& Salancik, G. R. (2003). The external control of organizations: A resource dependence perspective. Stanford University Press.

Porta, R. L., \& Shleifer, A. (2014). The unofficial economy in Africa. In African Successes: Sustainable Growth. University of Chicago Press.

Porter, M. E. (1994). The role of location in competition. Journal of the Economics of Business, 1(1), 35-40. http://dx.doi.org/10.1080/758540496

Porter, M. E. (2000). Location, competition, and economic development: Local clusters in a global economy. Economic development quarterly, 14(1), 15-34. http://dx.doi.org/10.1177/089124240001400105

Report of the Vision 2020. (July 2009). National Technical Working Group on Small and Medium Enterprises (SMEs). Retrieved from http://www.npc.gov.ng/vault/files/small\%20and\%20medium\%20enterprises\%20ntwg\%20report.pdf

Ropega, J. (2011). The reasons and symptoms of failure in SME. International Advances in Economic Research, 17(4), 476-483. http://dx.doi.org/10.1007/s11294-011-9316-1

Rowley, J. (2014). Designing and Using Research Questionnaires. Management Research Review, 37(3). 
http://dx.doi.org/10.1108/MRR-02-2013-0027

Ruzzier, M. K., Ruzzier, M., \& Hisrich, D. R. (2013). Marketing for Entrepreneurs and SMEs: A Global Perspective. Edward Elgar Publishing.

Teddlie, C., \& Fen Yu, F. (2007). Mixed methods sampling a typology with examples. Journal of Mixed Methods Research, 1(1), 77-100. http://dx.doi.org/10.1177/2345678906292430

Thompson, J. D. (2011). Organizations in action: Social science bases of administrative theory. Transaction Publishers.

Thornton, P. H., Ribeiro-Soriano, D., \& Urbano, D. (2011). Socio-cultural factors and entrepreneurial activity: An overview. International Small Business Journal.

Wernerfelt, B. (1995). The resource-based view of the firm: Ten years after. Strategic Management Journal, 16(3), 171-174. http://dx.doi.org/10.1002/smj.4250160303

\section{Copyrights}

Copyright for this article is retained by the author(s), with first publication rights granted to the journal.

This is an open-access article distributed under the terms and conditions of the Creative Commons Attribution license (http://creativecommons.org/licenses/by/3.0/). 